Kirja-arvio

\title{
Kansanperinteen ja kirjallisuuden rajamailla
}

Hämäläinen, Niina, Hanna Karhu ja Silja Vuorikuru (toim.). 2019.

Satuperinteestä nykyrunoon. Suullisen perinteen ja kirjallisuuden yhteyksiä. Helsinki: Suomalaisen Kirjallisuuden Seura. 326 sivua.

\section{Merja Leppälahti}

\begin{abstract}
A ikanaan kansanrunoudentutkimus arvosti erityisesti lukutaidottomien informanttien anteja, ja kirjoitetun vaikutus nähtiin alkuperäisen aineiston turmeltumisena; kirjoista opittua taas ei aina kannattanut merkitä muistiinkaan. Kirjallisuudentutkimus puolestaan keskittyi korkealaatuiseen arvokirjallisuuteen, ja suositutkaan populaarijulkaisut eivät ole aina sopineet tutkimuskohteiksi. Folkloristiikan ja kirjallisuudentutkimuksen tutkimusintressit ja menetelmät on pitkään nähty hyvin erilaisina. Viime vuosina tieteenalojen välillä on kuitenkin ruvettu etsimään myös yhteistä erottavien seikkojen lisäksi. Siihen saumaan sovittuvat tämänkin kirjan artikkelit. Kirjan kymmenessä artikkelissa yksitoista folkloristia ja kirjallisuudentutkijaa kirjoittaa teemoista, joissa yhdistyvät molempia kiinnostavat aiheet.

Toimittajien alkusanojen jälkeen kirja on jaettu kolmeen osaan. Ensimmäinen on otsikoitu nimellä Historiaa ja tieteenalojen taustoja, toinen Folkloristiikan ja kirjallisuudentutkimuksen yhteisiä kysymyksiä ja kolmas Kirjallisuudentutkimusta, tapaustutkimuksia.
\end{abstract}

\section{Johdantoa ja taustaa}

Kirjan ensimmäinen osa Historiaa ja tieteenalojen taustoja on hyvä johdanto teoksen aihepiiriin. Niina Hämäläinen, Hanna Karhu ja Silja Vuorikuru käsittelevät artikkelissaan "Suullisen perinteen ja kirjallisuuden rajoilla" tieteenalojen historiaa ja alkuaikojen työnjakoa. Keskeisinä eroina kansanperinteen ja kirjallisuuden välillä on nähty kysymys tekijyydestä sekä jako suulliseen ja kirjoitettuun. Tekstejä eroteltiin usein kansanperinteeseen ja taiteeseen, eikä siihen kiinnitetty paljoa huomiota, mitä niiden välille jäi. Kirjoittajat tarkastelevat myös Kalevalaa, joka on usein nähty liian kaunokirjallisena folkloristeille ja liian perinnelähtöisenä kirjallisuudentutkijoille.

Osion toinen artikkeli on Eija Starkin "Suullinen kulttuuri ja kirjallinen aineisto. Katsaus folkloristiikan historialliseen itseymmärrykseen" Stark tarkastelee artikkelissaan folkloristiikan syntyvaiheita tieteenalana. Hän on analysoinut professorien tekstejä, jotka antavat 
kuvan nuoren tieteenalan keskeisistä kysymyksistä, tavoitteista ja menetelmistä. Myös Stark tarttuu artikkelissaan kysymykseen Kalevalasta ja sen tutkimuksesta.

\section{Kansalta kirjoitettua}

Nautin suuresti lukiessani Satu Apon artikkelia "Tapaus Lumikki: kaunokirjallisesta fantasiakertomuksesta tulee kansansatu". Artikkelissa Apo tarkastelee Tatjana Huotarisen Pertti Virtarannalle kertomaa Lumisirkku-satua. Apo soveltaa artikkelissaan Lauri Hongon mallia kansakertomusten muuntelun tavoista ja toteaa lähteiden aukkoisuuden vaikeuttavan jäljittämistä. Tutkijan on esitettävä oletuksia ja liitettävä tulkintoihinsa varauksia, koska emme voi tietää, miten kaunokirjallisten Lumikkien kirjoittajat ovat tunteneet ja hyödyntäneet suullista perinnettä tai painotuotteita. Emme myöskään voi enää selvittää, millaisia Lumikki-satuja Tatjana Huotarinen on elämänsä aikana kuullut. Aukkoisuudesta huolimatta Apo pystyy varsin vakuuttavasti kuvaamaan Huotarisen Lumikki-sadun valintoja ja niiden taustoja.

Niina Hämäläinen ja Hanna Karhu käsittelevät suullisen perinteen matkaa kirjallisiksi runoiksi artikkelissaan "Elias Lönnrot, Otto Manninen ja tekstin tuottamisen prosessit". Lönnrotin tavoitteena oli luoda kirjallisia kokonaisuuksia, joissa kansanrunot ja niiden kantamat merkitykset säilyisivät mahdollisimman autenttisesti. Manninen taas kirjoitti kaunokirjallisia runoja kansanrunoja hyödyntäen. Lönnrotia ja Mannista käsitellään artikkelissa johdannon jälkeen erikseen loppuyhteenvetoon saakka. Kiinnostava aihe, josta olisi hyvin voinut tehdä myös kaksi erillistä artikkelia.

Kansankirjoittajat muodostavat mielenkiintoisen alueen lähes kirjoitustaidottoman "kansan" ja oppineiden välille. Anna Kuismin tarkastelee erään kansankirjoittajan kirjeitä artikkelissaan "'Kirjoitettu Warilan sepällä'. Suullinen perinne ja kirjallisuus Matti Matinpojan kirjeissä 1842-1847." Kuismin löytää Matti Matinpojan kirjeistä samantyyppisiä viittauksia kansanperinteeseen ja Raamattuun kuin Aleksis Kivi on hiukan myöhemmin käyttänyt teksteissään, erityisesti Seitsemässä veljeksessä (1870).

Eeva-Liisa Bastmanin artikkeli on nimeltään "Rakkauden kryytimaassa: Korkean veisun repertuaari kansanomaisessa ja kirjallisessa käytössä". Bastman lähtee liikkeelle Tuomas Ragvaldinpojan vuonna 1770 kirjoittamasta onnittelurunosta, joka on julkaistu myös arkkiveisuna, ja päätyy Helena Tuomaantytär Lindbomin 1850-luvulla julkaisemien virsien kautta Aleksis Kiven "Ruususolmu"-runoon ja P. Mustapään eli Martti Haavion runoon "Kansansävelmä". Bastman löytää runoista viitteitä Korkean veisun repertuaareihin kuten rakkauden yrttitarhaan. Rakkauden yrttitarha eli kryytimaa voi kuitenkin viitata sekä hengelliseen että maalliseen rakkauteen, ja sitä voidaan käyttää sekä ylevöittämisen että ironisoimisen välineenä.

\section{Kansanperinteen kaikuja kirjallisuudessa}

Kirjan kolmas osa painottuu kirjallisuuteen. Kirjallisuuden tapaustutkimukset aloittaa Viola Parente-Čapková, joka tarkastelee artikkelissaan muutamia Eino Leinon, Joel Lehtosen ja L. Onervan kuvaamia vanhoja naisia otsikolla "Vanhan naisen hahmo 1800- ja 1900-luvun vaihteen kirjallisuudessa: kansanrunouden ja sen tekstuaalisuuden kaikuja". Parente-Čapková löytää tarkastelemissaan teoksissa kolmenlaisia vanhenevia naisia: he näyttäytyvät kärsivinä äitihahmoina, allegorisina hirviöinä tai groteskeina kuvina entisestä kauneudesta. 
Irma Tapaninen tarkastelee artikkelissaan "Kansan nauru Algoth Untolan tyylin ja arvomaailman perustana" Maiju Lassilan nimellä kirjoitettujen teosten yhteyksiä kansan suulliseen nauruperinteeseen ja kiistämisen kulttuuriin. Karnevalistisen naurun kuvastoon liittyy Untolalla usein nenä sekä myös viina, poliisi ja putka.

Artikkelissaan "Äiti, ne ovat tärvelleet minun lauluni" Teemu Jokilaakso tarkastelee erilaisia suullisen perinteen muotoja, kuten loruja ja tarina-aineksia Monika Fagerholmin teoksissa Amerikkalainen tyttö (2004) ja Säihkenäyttämö (2009). Molemmissa romaaneissa esiintyy paljon lasten ja nuorten leikkejä ja tarinoita, jotka ovat suoraa lainaa tai sovellettua kansanperinnettä.

Myös Lena Gottelier on tarttunut 2000-luvun teksteihin artikkelissaan "Mitä annetaan, mitä ammennetaan. Ironinen lukutapa kansanlyriikan ja nykyrunouden liitoskohdissa". Gottelier käsittelee Ville Hytösen runoteoksen Karsikkopuu (2011) ja Teemu Mannisen teoksen Paha äiti (2012) suhdetta suulliseen kansanperinteeseen ironisen lukutavan kautta. Gottelier löytää teoksista mieskuvaa uudistavaa yhteiskunnallista ironiaa, joka liittyy nimenomaan kansanrunouden ja nykyrunouden liitoksiin.

\section{Tervetullut teos}

Satuperinteestä nykyrunoon painottuu kirjallisuudentutkimukseen. Yhdestätoista kirjoittajasta vain kolme on folkloristeja. Silti kaikissa kirjan artikkeleissa on myös folkloristin näkökulmasta kiinnostavaa asiaa, eniten kahdessa ensimmäisessä osiossa. Kirjan ensimmäinen osa - Historiaa ja tieteenalojen taustoja - sisältää sellaisia perusasioita, että se kannattaisi sisällyttää opiskelijoiden lukemistoon.

Itsekin folkloristiikan ja kirjallisuudentutkimuksen rajamailla liikkuessani olen joutunut toteamaan, että tältä alueelta ei ole kovin paljon kirjallisuutta. Artikkelikokoelma Satuperinteestä nykyrunoon on siis paitsi ansiokas myös erittäin tervetullut lisä tutkimuskirjallisuuteen. Kirjan hyödyllisyyttä lähdeteoksena lisäävät loppuun sijoitetut erilliset asia-, henkilö- ja teoshakemistot.

Filosofian lisensiaatti Merja Leppälahti on tietokirjailija ja kirjallisuuskriitikko sekä folkloristiikan tohtorikoulutettava Turun yliopistossa. 